\title{
Parasites of the Neotropic cormorant Nannopterum (Phalacrocorax) brasilianus (Aves, Phalacrocoracidae) in Chile
}

\author{
Parasitos da biguá Nannopterum (Phalacrocorax) brasilianus \\ (Aves, Phalacrocoracidae) do Chile \\ Daniel González-Acuña1* (D); Sebastián Llanos-Soto1,2; Pablo Oyarzún-Ruiz (1); John Mike Kinsella; \\ Carlos Barrientos ${ }^{4}$; Richard Thomas ${ }^{1}$; Armando Cicchino5; Lucila Moreno ${ }^{6}$ \\ ${ }^{1}$ Laboratorio de Parásitos y Enfermedades de Fauna Silvestre, Departamento de Ciencia Animal, Facultad de Medicina Veterinaria, \\ Universidad de Concepción, Chillán, Chile \\ ${ }^{2}$ Laboratorio de Vida Silvestre, Departamento de Ciencia Animal, Facultad de Medicina Veterinaria, Universidad de Concepción, Chillán, Chile \\ ${ }^{3}$ Helm West Lab, Missoula, MT, USA \\ ${ }^{4}$ Escuela de Medicina Veterinaria, Universidad Santo Tomás, Concepción, Chile \\ ${ }^{5}$ Universidad Nacional de Mar del Plata, Mar del Plata, Argentina \\ ${ }^{6}$ Facultad de Ciencias Naturales y Oceanográficas, Universidad de Concepción, Concepción, Chile
}

How to cite: González-Acuña D, Llanos-Soto S, Oyarzún-Ruiz P, Kinsella JM, Barrientos C, Thomas R, et al. Parasites of the Neotropic cormorant Nannopterum (Phalacrocorax) brasilianus (Aves, Phalacrocoracidae) in Chile. Braz J Vet Parasitol 2020; 29(3): e003920. https://doi.org/10.1590/S1984-29612020049

\begin{abstract}
The Neotropic cormorant Nannopterum (Phalacrocorax) brasilianus (Suliformes: Phalacrocoracidae) is widely distributed in Central and South America. In Chile, information about parasites for this species is limited to helminths and nematodes, and little is known about other parasite groups. This study documents the parasitic fauna present in 80 Neotropic cormorants' carcasses collected from 2001 to 2008 in Antofagasta, Biobío, and Ñuble regions. Birds were externally inspected for ectoparasites and necropsies were performed to examine digestive and respiratory organs in search of endoparasites. Ectoparasites collected were cleared and mounted for identification under a microscope. Fecal samples were also evaluated to determine the presence of protozoan parasites employing a flotation technique. A total of $44(42.5 \%)$ of birds were infested with at least one ectoparasite species, while 77 (96.25\%) were carrying endoparasites. No protozoan forms were found after examination. Most prevalent endoparasite species found were Contracaecum rudolphii s. I. (72/80, 90\%), followed by Pectinopygus gyroceras (33/80, 41.25\%), and Profilicollis altmani (26/80, 32.5\%). This is the first report of P. altmani, Baruscapillaria carbonis, Avioserpens sp., Cyathostoma (Cyathostoma) phenisci, and Eidmaniella pelucida in the Neotropic cormorant. These findings also expand the distributional range of Andracantha phalacrocoracis, Paradilepis caballeroi, Hysteromorpha triloba, and P. gyroceras to Chile.
\end{abstract}

Keywords: Helminths, ectoparasites, endoparasites, birds, lice.

\section{Resumo}

O Biguá Nannopterum (Phalacrocorax) brasilianus (Suliformes: Phalacrocoracidae) é amplamente distribuído na América Central e na do Sul. No Chile, as informações sobre parasitos para essa espécie são limitadas a helmintos e nematoides, e pouco se sabe sobre outros grupos de parasitos. Este estudo documenta a fauna parasitária presente em 80 biguás coletados de 2001 a 2008, nas regiões de Antofagasta, Biobío e Ñuble. As aves foram inspecionadas externamente em busca de ectoparasitas; adicionalmente, foram realizadas necropsias para examinar os órgãos digestivos e respiratórios em busca de endoparasitos. Os ectoparasitos coletados foram limpos e montados para identificação ao microscópio. As amostras de fezes também foram avaliadas para determinar a presença de parasitos protozoários, empregando-se uma técnica de flutuação. Um total de $44(42,5 \%)$ aves estavam infectadas com pelo menos um ectoparasito, enquanto $77(96,25 \%)$ estavam portando endoparasito. Nenhuma forma de protozoário foi encontrada após o exame. As espécies de endoparasitos mais prevalentes encontradas foram Contracaecum rudolphii (72/80, 90\%), Pectinopygus gyroceras (33/80, 41.25\%) e Profilicollis altmani (26/80, 32.5\%). Este 
é o primeiro registro de P. altmani, Baruscapillaria carbonis, Avioserpens sp., Cyathostoma (Cyathostoma) phenisci e Eidmaniella pelucida no biguá. Esses resultados também expandem a distribuição de Andracantha phalacrocoracis, Paradilepis caballeroi, Ascocotyle felippei, Hysteromorpha triloba e P. gyroceras no Chile.

Palavras-chave: Helmintos, parasitas externos, parasitas internos, pássaro, piolhos.

\section{Introduction}

The Neotropic cormorant Nannopterum (Phalacrocorax) brasilianus (Suliformes: Phalacrocoracidae) is a widely distributed bird of Central and South America, reaching Mexico and the southern areas of the United States (Kennedy \& Spencer, 2014; IUCN, 2017). It feeds on crustaceans, small fish, amphibians, and insects in different aquatic habitats with fresh, brackish, or saltwater (IUCN, 2017). In Chile, the Neotropic cormorant is distributed in marine coasts, lakes, and rivers from Arica $\left(18^{\circ} 28^{\prime} 30^{\prime \prime} \mathrm{S}, 70^{\circ} 18^{\prime} 52^{\prime \prime} \mathrm{W}\right)$ to Tierra del Fuego $\left(53^{\circ} 36^{\prime} 00^{\prime \prime} \mathrm{S}, 69^{\circ} 23^{\prime} 00^{\prime \prime} \mathrm{W}\right)$. It comprises two subspecies $N$. (P.) b. brasilianus and $N$. $(P)$.$b . hornensis, with the latter being distributed along$ the Beagle Channel and Cape Horn in southern Chile (Chester, 2008). As established by the Chilean Hunting Law $N^{\circ} 19.473$, the Neotropic cormorant is a pest bird in some regions of northern Chile (SAG, 2018).

Currently, the Neotropic cormorant does not face conservation issues, having an increasing population of more than 2 million individuals and a large distributional range (IUCN, 2017). However, it is still important to elucidate parasite species that might be affecting the health of Neotropic cormorants, particularly younglings, which are more susceptible to develop disease due to parasitism (Kuiken et al., 1999; Torres et al., 2005). Most surveys of the parasitic fauna of the Neotropic cormorant have been performed in Brazil, Argentina, Mexico, and the United States (Vicente et al., 1996; Fedynich et al., 1997; Drago et al., 2011; Monteiro et al., 2011). Information about its parasites in Chile is restricted to studies performed by Torres et al. (1982, 1991, 1992, 1993, 2000, 2005) and Garbin et al. (2011).

Previous studies of endoparasites in the Neotropic cormorant indicate the presence of Nematoda from genera Eucoleus, Ornithocapillaria, Capillaria, Contracaecum, Baruscapillaria, Syncuaria, Porrocaecum, Anisakis, Pseudoterranova, Eustrongylides, Syngamus, and Tetrameres (Lamont, 1920; Vicente et al., 1995, 1996; Torres et al., 1991, 2005; Monteiro et al., 2006b, 2011; Garbin et al., 2011; Violante-González et al., 2011); four Acanthocephala species from genera Andracantha, Corynosoma, and Southwellina (Torres et al., 1992; Hinojosa-Sáez \& González-Acuña, 2005; Monteiro et al., 2006a, 2011; Violante-González et al., 2011); 28 species of Trematoda from genera Strigea, Tylodelphys, Neodiplostomum, Austrodiplostomum, Hysteromorpha, Euhaplorchis, Mehrastomum, Ribeiroia, Odhneria, Drepanocephalus, Ascocotyle, Maritrema, Phocitremoides, Pseudopsilostoma, Echinochasmus, Prosthogonimus, Clinostomatopsis, Clinostomum, Diplostomum, Ignavia, and Paryphostomum (Fedynich et al. 1997; Lunaschi \& Drago, 2005; Monteiro et al., 2007, 2011; Drago et al., 2011; Violante-González et al., 2011); and two Cestoda from genera Paradilepis and Tetrabothrius sp. (Fedynich et al., 1997; Hinojosa-Sáez \& González-Acuña, 2005; Monteiro et al., 2011; Violante-González et al., 2011).

There are few descriptions of ectoparasites in the Neotropic cormorant. For instance, lice Piagetiella vigua Eichler, 1943, Eidmanniella eurygaster Nitzsch, 1866, Pectinopygus faralloni Kellogg, 1896, Pectinopygus gyrocera Nitzsch, 1866, Pectinopygus depressus Rudow, 1869, Colpocephalum commune Rudow, 1869, and Laemobothrion brasiliense Rudow, 1869 (Malcomson, 1960; Price, 1970); fleas Ceratophyllus titicacensis Smit, 1978 (Hastriter, 2001); mites Scutomegninia microfalcifera Mironov, 1990, Plicatalloptes sp. Dubinin, 1955, Michaelia neotropica Mironov \& Hernandes, 2016, Frehelectes gaudi Fain, 1984, Neottialges evansi Fain, 1966, Dinalloptes chelionatus Atyeo e Peterson, 1966, and Allopsoroptoides galli Mironov, 2013 (Pence et al., 1997; Mironov, 2000; Barreto et al., 2012; Mironov, 2013; Tucci et al., 2014; Pedroso \& Hernandes, 2016; Hernandes et al., 2016); and hippoboscids Olfersia sordida Bigot, 1885 (Santos et al., 2014).

There are no reports of protozoa parasites in the Neotropic cormorants or any other cormorant species in Chile. However, there are records of Toxoplasma gondii, Cryptosporidium sp., Giardia sp., Entamoeba sp., Eimeria sp., and Sporozoa (Apicomplexa) oocyst in the great (Phalacrocorax carbo) and flightless cormorants (Phalacrocorax harrisi) (Medema, 1999; Plutzer \& Tomor, 2009; Deem et al., 2010; Carrera-Jativa et al., 2014; Víchová et al., 2016; Rzymski et al., 2017). Certain fish species act as reservoirs of Cryptosporidium sp. (Gabor et al., 2011), and Giardia sp. (Ghoneim et al., 2012), underlining the role that cormorants might play as reservoirs of protozoan parasites due to their elevated fish consumption (Carss, 1997). Nonetheless, the importance that the Neotropic cormorant has in the maintenance of parasites in terrestrial and aquatic environments remains to be determined.

In South America, studies of the parasitic fauna of the Neotropic comorant have been mainly carried out in Brazil (Vicente et al., 1996; Monteiro et al., 2011) and Argentina (Drago et al., 2011). In Chile, information about parasites for this bird is restricted to studies performed by Torres et al. $(1982,1991,1992,1993,2000,2005)$ and 
Garbin et al. (2011), in which only the presence of nematodes and other helminths was reported. Due the current lack of knowledge about the parasitic fauna of Neotropic cormorants in Chile, this study aimed to document new records of the ecto-, endoparasites, and protozoa of this widely distributed bird in the country. Additionally, most cormorants included in this study were residents of Talcahuano and San Vicente Bay, both areas characterized by the presence of estuarine wetlands and marshes, which are usually visited by resident and migratory birds to rest and feed (León \& Benítez-Mora, 2005; García-Walther et al., 2017). Encounters among diverse bird species in these areas provide opportunities for the transmission of different parasite groups (Bjoersdorff et al., 2001), highlighting the importance of determining parasitic organisms in these birds to better understand parasite-host interactions in the established ecological communities.

\section{Materials and Methods}

Eighty Neotropic cormorants were hunted in years 2001 (1), 2002 (1), 2003 (4), 2005 (1), 2006 (1), 2007 (64), and 2008 (8) from four locations of the Biobío region: Talcahuano $\left(36^{\circ} 43^{\prime} \mathrm{S}, 73^{\circ} \mathrm{O} 6^{\prime} \mathrm{W}\right)$, Lenga $\left(36^{\circ} 47^{\prime} \mathrm{S}, 73^{\circ} 02^{\prime} \mathrm{W}\right)$, Infiernillo $\left(36^{\circ} 35^{\prime} \mathrm{S}, 72^{\circ} 31^{\prime} \mathrm{W}\right)$, San Vicente Bay $\left(36^{\circ} 44^{\prime} \mathrm{S}, 73^{\circ} 07 \mathrm{~W}\right)$; two locations from the Ñuble region: Chillán $\left(36^{\circ} 36^{\prime} \mathrm{S}, 72^{\circ} 06^{\prime} \mathrm{W}\right)$ and Santa Elena Lake $\left(36^{\circ} 48^{\prime} \mathrm{S}, 72^{\circ} 22^{\prime} \mathrm{W}\right)$, and a single location in the Antofagasta region $\left(23^{\circ} 39^{\prime} \mathrm{S}\right.$, $70^{\circ} 23^{\prime} \mathrm{W}$ ) (Figure 1). Cormorants collected from Talcahuano and San Vicente (Chile) in 2007 died because of an oil spill event that occurred in the area during the same year. All other carcasses examined in this study were donated by hunters. The Chilean Hunting Law $\mathrm{N}^{\circ} 19.473$, Article N 5, Supreme decree $\mathrm{N}^{\circ} 5$, allows hunting of Neotropic cormorants along its distributional range from April to August. All carcasses were brought to the Department of Animal Science, Universidad de Concepción, Chillán, and kept stored at $-40{ }^{\circ} \mathrm{C}$ for future examination.

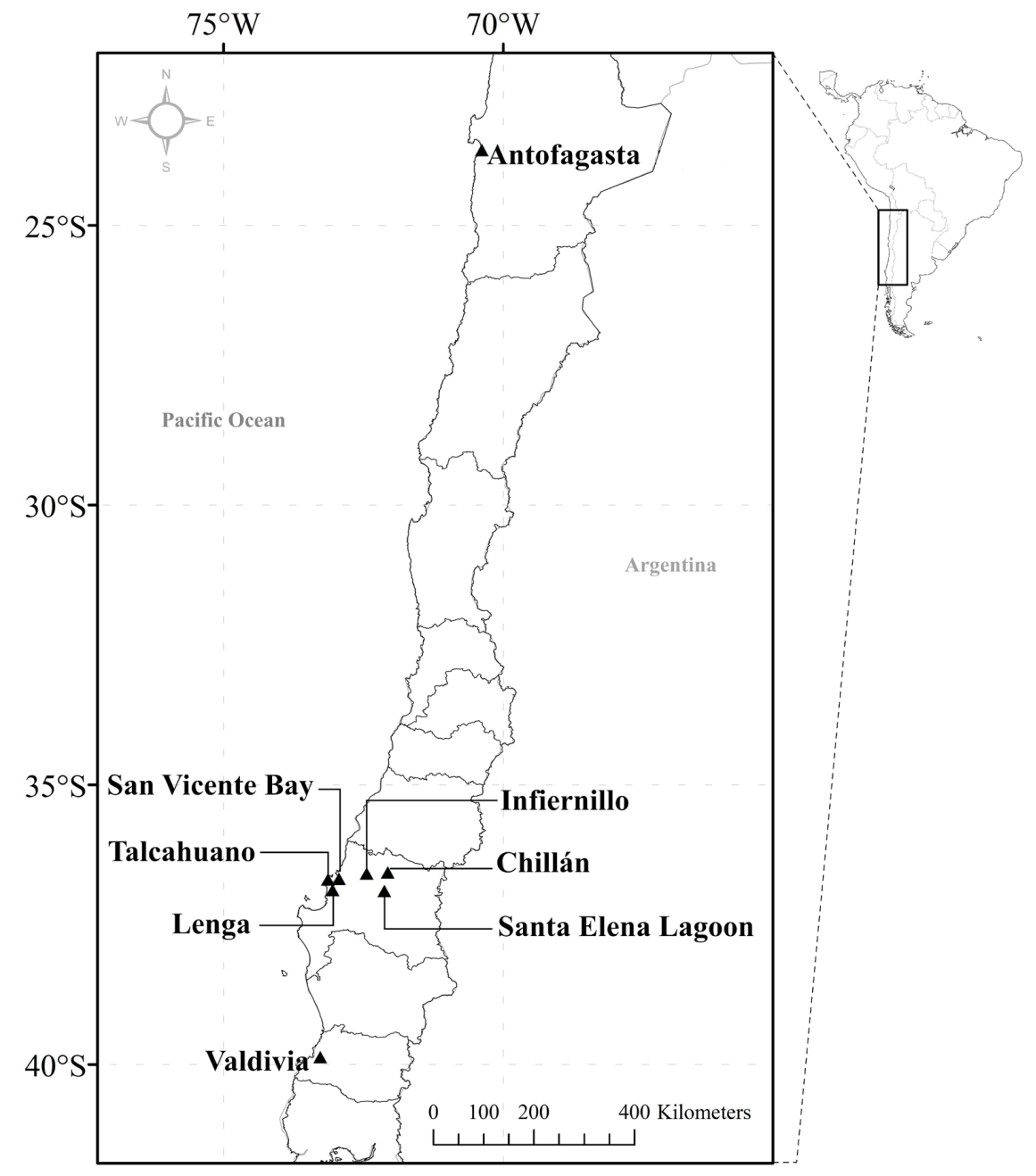

Figure 1. Map of Chile showing the sampling locations. 
Cormorants were externally inspected with a magnifier in search of ectoparasites. Feathers of the wings, tail, head, neck, flanks, back, and abdomen were closely examined. As birds were dead when they were collected, it is possible that ectoparasites may have abandoned their hosts after their death. Following collection, lice were cleared using $20 \% \mathrm{KOH}$ and ascending concentrations of ethanol solutions (40\%,70\%, and $96 \%)$ and were subsequently mounted using Canada balsam, as indicated in Palma (1978) and Price et al. (2003). Ectoparasites were identified using the keys provided in Giebel (1866), Keler (1938), Ryan \& Price (1969), Clay (1973), Price et al. (2003), and Kuabara \& Valim (2017).

Birds were necropsied using the modified Withlock technique (Cattán \& Tagle, 1974). Digestive and respiratory organs were inspected in search of endoparasites and some segments of the intestine were observed with the stereomicroscope (20x and 40x) in order to collect parasites that could have been adhered to the mucous membrane. Endoparasites were stored following methods in Pritchard \& Kruse (1982). Trematoda were preserved in $70 \%$ ethyl alcohol and stained with carmine and alum carmine stains for identification. Acanthocephalans and cestodes were maintained in water for 10 min and then kept in 10\% buffered formalin and a mix of 70\% ethyl alcohol and 10\% lactic acid, respectively. Nematoda were preserved in $70 \%$ ethyl alcohol and then fixated with glycerin in 50-100 mL flasks (Oyarzún-Ruiz \& González-Acuña, 2020). Endoparasites were identified using keys and descriptions in Skrjabin et al. (1954), Skrjabin (1961, 1969), Yamaguti (1958, 1959, 1961), and Khalil et al. (1994). A fecal sample was obtained from the distal rectum of each bird in order to search for intestinal protozoa using the flotation technique described in Boch \& Supperer (1982).

The terminology used to describe parasitological assemblage descriptors (prevalence, mean intensity, and mean abundance) follows that of Bush et al. (1997). 'Range' displays the minimum and maximum number of individuals of a parasite species collected from the least and most infested hosts, respectively.

\section{Results and Discussion}

\section{Ectoparasites}

Thirty-four (42.5\%) birds were parasitized by at least one species of ectoparasite. Eidmaniella pelucida Rudow, 1869 (Figure 2a) and Pectinopygus gyroceras (Figure 2b) were identified as lice species in the Neotropic Cormorant. The ratios of nymph/adult and male/female for $P$. gyroceras were 0.81 and 1.67, respectively ( 70 females, 42 males and 91 nymphs). Only a single individual $E$. pelucida was collected. Information about population parameters for P. gyroceras can be found in Table 1.
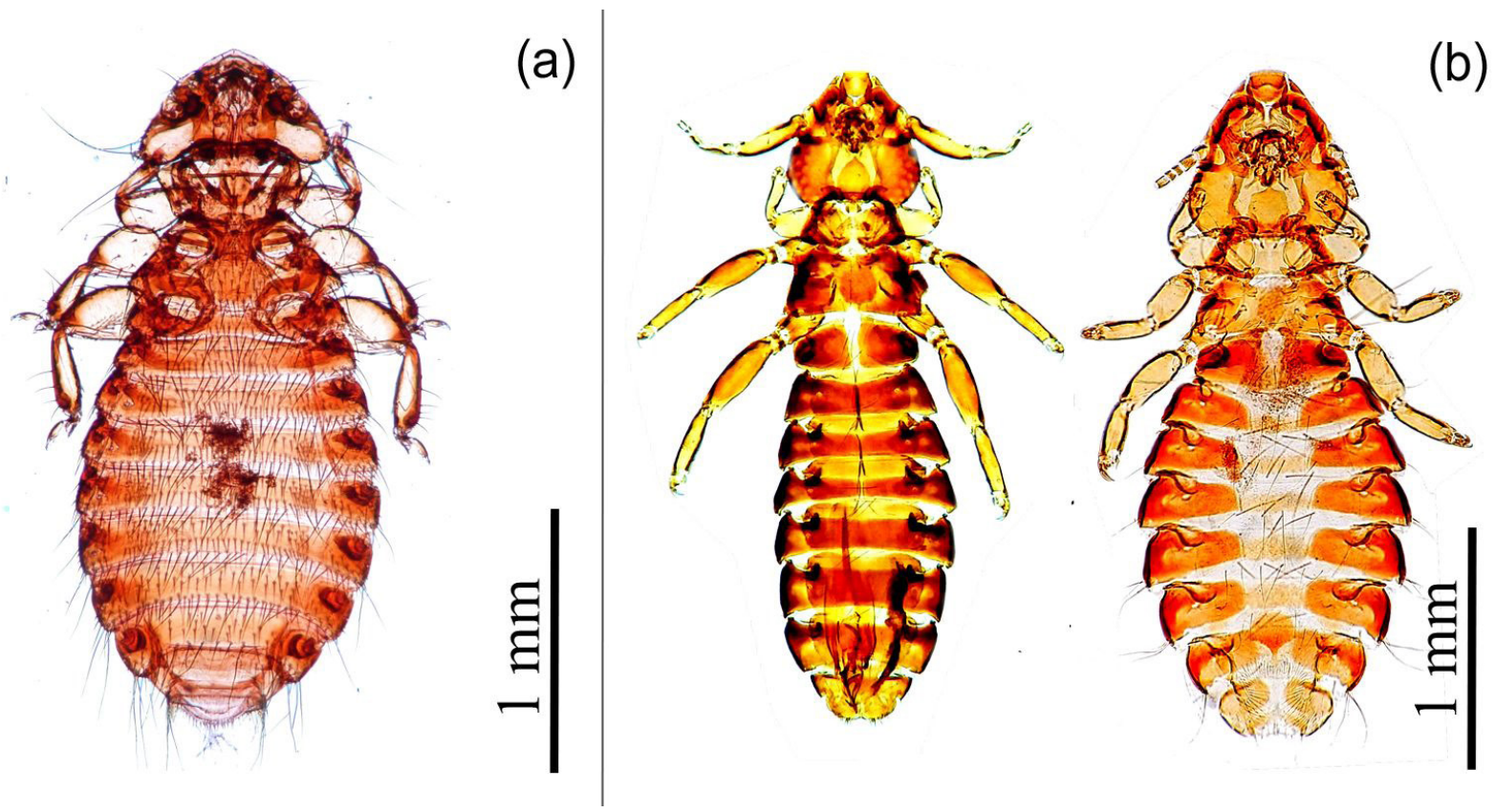

Figure 2. (a) Female specimen of Eidmaniella pelucida (100x magnification); (b) Male (left) and female (right) Pectinopygus gyroceras (100x magnification). 
Table 1. Parasitological descriptors of ecto- and endoparasites collected from Neotropic cormorants (Nannopterum (Phalacrocorax) brasilianus).

\begin{tabular}{|c|c|c|c|c|c|c|c|c|}
\hline \multirow{2}{*}{ Species } & \multirow{2}{*}{ Habitat } & \multirow{2}{*}{$\begin{array}{l}\text { Positive } \\
\text { birds }\end{array}$} & \multicolumn{2}{|c|}{ Intensity } & \multirow{2}{*}{$\begin{array}{c}\text { Mean } \\
\text { abundance }\end{array}$} & \multirow{2}{*}{$\begin{array}{l}\text { Standard } \\
\text { deviation }\end{array}$} & \multirow{2}{*}{$\begin{array}{c}\text { Prevalence } \\
(\%)\end{array}$} & \multirow{2}{*}{ Tota } \\
\hline & & & Mean & Range & & & & \\
\hline \multicolumn{9}{|l|}{ Phthiraptera } \\
\hline Pectinopygus gyroceras & Feathers & 33 & 6.15 & $1-28$ & 2.54 & 34.35 & 41.25 & 203 \\
\hline \multicolumn{9}{|l|}{ Trematoda } \\
\hline Ascocotyle felippei & $\begin{array}{c}\text { Small and large } \\
\text { intestines }\end{array}$ & 10 & 52.1 & $1-250$ & 6.51 & 35.71 & 12.5 & 521 \\
\hline Hysteromorpha triloba & $\begin{array}{l}\text { Small and large } \\
\text { intestines }\end{array}$ & 2 & 2467 & $150-4784$ & 61.68 & 534.9 & 2.5 & 4934 \\
\hline \multicolumn{9}{|l|}{ Nematoda } \\
\hline Anisakis sp. & Stomach & 1 & - & - & - & - & 1.25 & 36 \\
\hline Avioserpens sp. & Stomach & 1 & - & - & - & - & 1.25 & 2 \\
\hline Baruscapillaria carbonis & Stomach & 1 & - & - & - & - & 1.25 & 1 \\
\hline Contracaecum rudolphii s. I. & Stomach & 72 & 41 & $1-280$ & 36.69 & 48.48 & 90 & 2935 \\
\hline $\begin{array}{c}\text { Cyathostoma } \\
\text { (Cyathostoma) phenisci }\end{array}$ & Trachea & 1 & - & - & - & - & 1.25 & 1 \\
\hline \multicolumn{9}{|l|}{ Acanthocephala } \\
\hline $\begin{array}{l}\text { Andracantha } \\
\text { phalacrocoracis }\end{array}$ & $\begin{array}{l}\text { Small and large } \\
\text { intestines }\end{array}$ & 9 & 4.11 & $1-12$ & 2.79 & 8.54 & 17.5 & 223 \\
\hline Corynosoma arctocephali & $\begin{array}{l}\text { Small and large } \\
\text { intestines }\end{array}$ & 14 & 15.93 & $1-46$ & 0.46 & 1.79 & 11.25 & 37 \\
\hline Profilicollis altmani & $\begin{array}{l}\text { Small and large } \\
\text { intestines }\end{array}$ & 26 & 25.04 & $2-80$ & 8.14 & 16.22 & 32.5 & 651 \\
\hline \multicolumn{9}{|l|}{ Cestoda } \\
\hline Paradilepis caballeroi & Small intestine & 3 & 73.33 & $2-183$ & 2.75 & 31.77 & 3.75 & 220 \\
\hline
\end{tabular}

Information about both ectoparasite species found in this study is extremely sparse. Eidmaniella pelucida was recorded in Phalacrocorax capensis and P. carbo in North America, P. carbo in Spain, and Leucocarbo bougainvillii (Phalacrocoracidae) in Peru (Emerson, 1947; Dale, 1970; Mateo, 2006). Similarly, P. gyroceras has been previously described in N. (P.) brasilianus in the United States and Brazil (Malcomson, 1960; Kuabara \& Valim, 2017). This is the first time that E. pelucida is described in the Neotropic cormorant and expands the distributional range of $P$. gyroceras to Chile.

It is important to highlight that pollution with hydrocarbons could have resulted in a less intense infestation with ectoparasites in cormorants from Talcahuano and San Vicente Bay. This, because hydrocarbons adhere to feathers and cause a should be disruption of the water repellent properties of birds' plumage (Jenssen, 1994), allowing polluted water to cover feathers and remove ectoparasites. Moreover, affected feathers lose their ability to provide insulation and leads to hypothermia in birds, which might have caused ectoparasites to abandon their now dead hosts before carcasses arrived at the university for inspection. Parasites could have also been washed away when cleaning birds affected by the oil. All these effects of hydrocarbons could have led to a sub-estimation of ectoparasite abundance, intensity, and prevalence.

\section{Endoparasites}

From the 80 birds examined, 77 (96.25\%) were infected with at least one species of endoparasite. A total of 9566 parasites were collected in total: 5455 Trematoda (57.02\%), 2979 Nematoda (31.14\%), 911 Acanthocephala (9.52\%), and 221 Cestoda (2.31\%). 
No protozoan parasites were detected in this study during faecal examination. Previously, protozoan from the genera Giardia and Cryptosporidium have been informed in feces from P. carbo through microscopy (Medema, 1999; Rzymski et al., 2017) and PCR (Plutzer \& Tomor, 2009). It is important to consider that the absence of protozoa oocysts and eggs observed in this study does not necessarily mean that birds were free of these parasites, but could be a result of factors associated with the low sensitivity of the flotation technique and/or low infestation rate (Zajac \& Conboy, 2012). It is recommended for future studies to employ more sensitive techniques, such as molecular methods, to precisely diagnose protozoan parasite infection (Plutzer \& Tomor, 2009).

\section{Trematoda}

Trematode species Hysteromorpha triloba (Figure 3a) and Ascocotyle felippei (Figure 3b) were identified and were isolated from two and ten cormorants, respectively. Hysteromorpha triloba was the most abundant parasite with 4784 individuals found in a single bird. Information about population parameters for Trematoda recorded in this study can be found in Table 1.

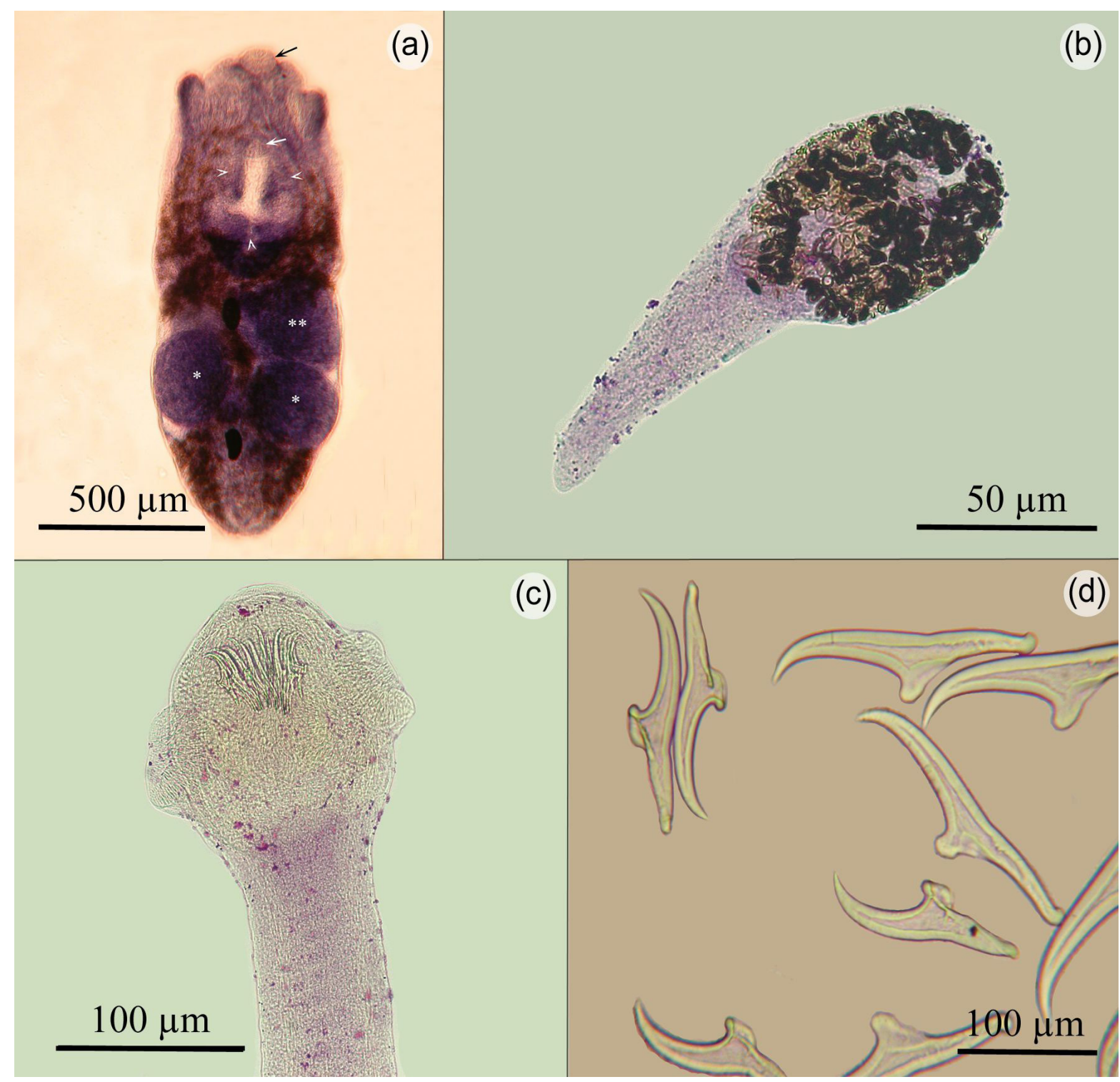

Figure 3. (a) Photomicrographs of an adult Hysteromorpha triloba in toto with its trilobulated forebody, small oral sucker (black arrow) and oval ventral sucker (white arrow) covered by the holdfast organ (white arrow heads). The anterior oval testis is denoted by double asterisk and the posterior bilobulated testis each by single asterisk (200x magnification); (b) Ascocotyle felippei mature fluke with its typical pear-shaped body and its uterus filled with eggs. Post-mortem autolytic changes account for the absence of typical cephalic spines (100x magnification); (c, d) Paradilepis caballeroi with its (c) scolex bearing well-developed suckers (arrows) and an invaginated rostellum (arrowhead) (40x magnification); (d) Typical hooks for this species (400x magnification). 


\section{H. triloba}

Hysteromorpha triloba is a cosmopolitan parasite that infects snails and fishes as first and second intermediate hosts, respectively, reaching piscivorous birds as their definitive hosts (Hugghins, 1954a, b). It is commonly found in cormorants, being described in different cormorant species and found in several countries. For instance, it has been reported in Nannopterum (Phalacrocorax) auritus in the United States and Canada (Chandler \& Rausch, 1948), Microcarbo melanoleucos and Phalacrocorax fuscescens in Australia (Johnston, 1942), and P. carbo in Mongolia, Ukraine, Czech Republic, Curonian Lagoon Area (Russia and Lithuania), India, Japan, Australia, and Poland (Yamaguti, 1939; Johnston, 1942; Gupta, 1963; Našincová et al., 1993; Kanarek et al., 2003; Kornyushin, 2008; Švažas et al., 2011; Lebedeva \& Chantuu, 2015). Hysteromorpha triloba has been previously recorded in the Neotropic cormorant in Argentina, Brazil, and the United States (Fedynich et al., 1997; Drago et al., 2011; Monteiro et al., 2011), however, this is the first time that it is reported in the Neotropic cormorant in Chile.

\section{A. felippei}

Species of the genus Ascocotyle infect snails and fishes as intermediate hosts and are common parasites of piscivorous birds and mammals, which serve as the definitive host (Ostrowski de Núñez, 1976). Ascocotyle felippei has been reported in different bird species of the American continent. For instance, it has been recorded in Egretta caerulea, Egretta tricolor, and Botaurus lentiginosus (Ardeidae) in the United States (Price, 1935; Leigh, 1956; Sepúlveda et al., 1996); Himantopus melanurus (Recurvirostridae), Butorides striata, Ixobrychus involucris (Ardeidae) Spheniscus magellanicus (Spheniscidae), and Nycticorax nycticorax (Ardeidae) in Argentina (Boero et al., 1972; Ostrowski de Núñez, 1976; Alda et al., 2011); Ardea alba (Ardeidae) in Mexico and the United States (Aguirre-Macedo \& García-Magaña, 1994; Sepúlveda et al., 1999); Ardea herodias (Ardeidae) and Buteogallus anthracinus (Accipitridae) in Mexico (Aguirre-Macedo \& García-Magaña, 1994; Scholz et al., 2001); Ixobrychus exilis (Ardeidae) in Brazil (Travassos et al., 1969), and Falco sparverius (Falconidae) in Chile (Moreno \& González-Acuña, 2015). Ascocotyle felippei has been previously described in Neotropic cormorants in the United States and Mexico (Fedynich et al., 1997; Scholz et al., 2001) but it constitutes a new report for this species in Chile.

\section{Cestoda}

Paradilepis caballeroi (Figure 3c, d) was the only cestode isolated from cormorant carcasses. Information about population parameters for the species in this study can be found in Table 1.

\section{P. caballeroi}

Adults of the genus Paradilepis Hsü, 1935 are parasites of Pelecaniformes and, in many cases, cormorants (Presswell et al., 2012). It consists of fourteen species, Paradilepis delachauxi Fuhrmann, 1909, Paradilepis diminuta Huey \& Dronen, 1981, Paradilepis kempi Southwell, 1921, Paradilepis longivaginosus Mayhew, 1925, Paradilepis maleki Khalil, 1961, Paradilepis urceina Bona, 1975, Paradilepis phalacrocoracis Ukoli, 1968, Paradilepis minima Goss, 1914, Paradilepis patriciae Baer \& Bona, 1960, Paradilepis rugovaginosus Freeman, 1954, Paradilepis scolecina Rudolphi, 1819, Paradilepis simoni Rausch, 1949, Paradilepis urceus Wedl, 1855, and P. caballeroi (Presswell et al., 2012). The latter species has been found in Pelecanus occidentalis (Pelecanidae) and $N$. (P.) auritus in the United States (Fedynich et al., 1997; Forrester \& Spalding, 2003), N. (P.) auritus in Canada (Robinson, 2011), N. (P.) brasilianus, P. occidentalis, Pelecanus erythrorhynchos (Pelecanidae), and Platalea ajaja (Threskiornithidae) in Mexico (Scholz et al., 2002; Ortega-Olivares et al., 2014), N. (P.) auritus in Cuba (Scholz et al., 2002) and N. (P.) brasilianus in Brazil (Monteiro et al., 2011). This is the first time that $P$. caballeroi has been reported in Chile.

\section{Nematoda}

Five nematode species were isolated from Neotropic cormorants' carcasses, Anisakis sp. (Figure 4a), Baruscapillaria carbonis Dubinin \& Dubinina 1940, Avioserpens sp. Wehr \& Chitwood 1934 (Figure 4b, c), Cyathostoma (Cyathostoma) phenisci Baudet, 1937 (Figure 4d), and Contracaecum rudolphii s. I. (Rudolphi, 1809) Hartwich, 1964 (Figure 4e).

Anisakis sp. and C. rudolphii s. I. has been previously recorded in the Neotropic cormorant and C. (C.) phenisci has been described for the Imperial shag in Chile (Torres et al., 1982, 2005; Oyarzún-Ruiz \& Muñoz-Alvarado, 2015). This is the first report of $C$. (C.) phenisci in the Neotropic cormorant. Information about population parameters for Nematoda recorded in this study can be found in Table 1. 


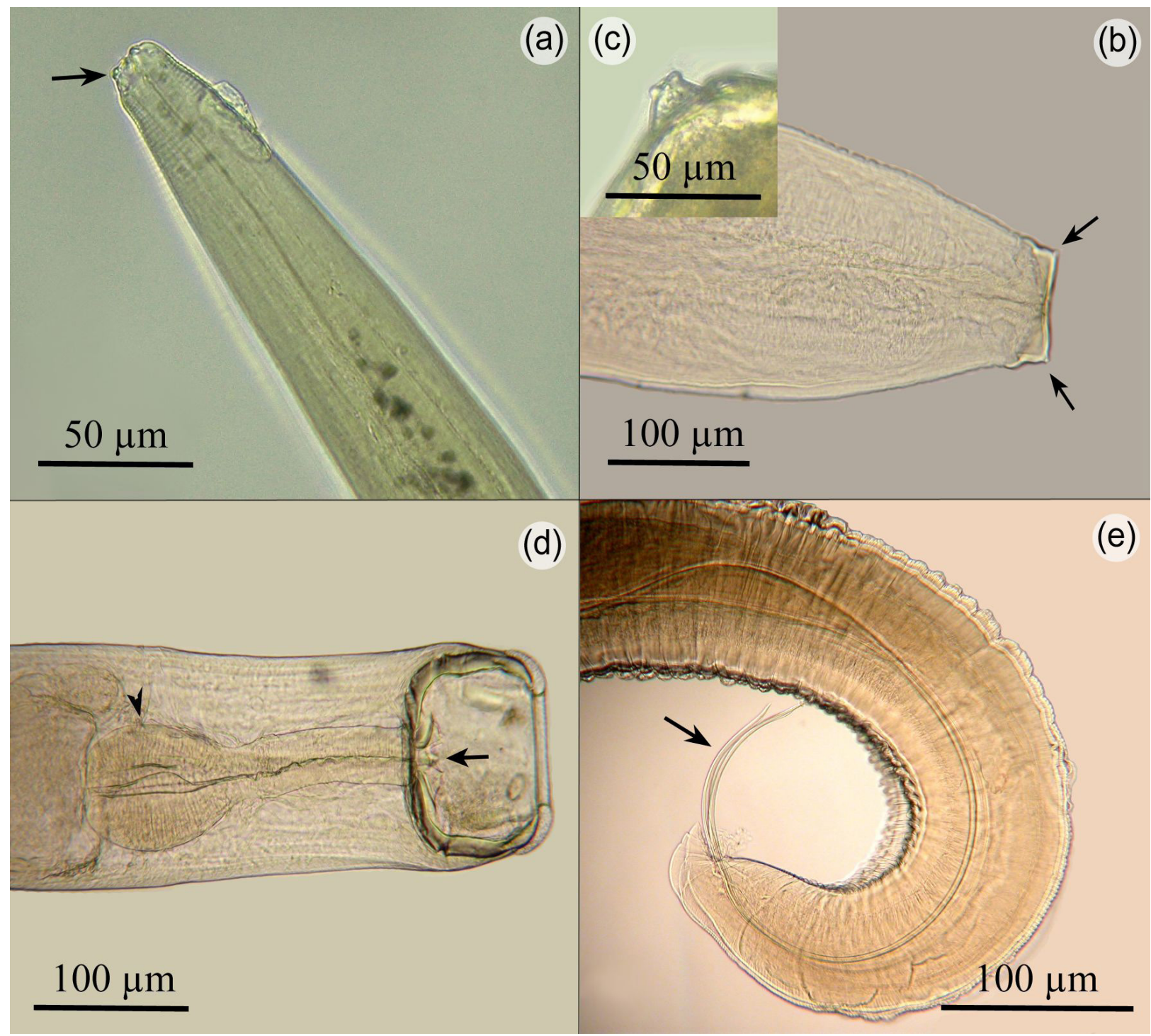

Figure 4. (a) View of anterior end of Anisakis sp. larva showing the presence of boring tooth (arrow) and lips forming medial bilobed process without interlabia (250x magnification); (b, c) Photomicrographs of Avioserpens sp. displaying the (b) anterior view end bearing two double cephalic papillae (arrows) (40x magnification); (c) and magnification of a cephalic papillae (500x magnification); (d) View of an individual from Cyathostoma (Cyathostoma) phenisci showing its anterior end with a wide buccal capsule bearing six teeth at its basis (arrow) and its muscular esophagus dilated at its caudal third (arrowhead) (400x magnification); (e) View of posterior end from a male Contracaecum rudolphii s. I. displaying its long and thin pair of subequal spicules (arrow) (400x magnification).

\section{B. carbonis}

Baruscapillaria carbonis is a specialist parasite of cormorants and it is suggested that fish may play an important role in its development and transmission (Frantová, 2001). Baruscapillaria carbonis has been described in P. carbo and Microcarbo pygmaeus in the European continent (Baruš \& Sergeeva, 1990; Frantová, 2001; Sitko \& Okulewicz, 2010; Kanarek \& Zaleśny, 2014). Baruscapillaria carbonis has been reported in other fish-eating hosts in the Palearctic region, but those records are considered dubious as they were not properly described (Baruš et al., 1978; Moravec et al., 1994). This study is the first record of B. carbonis in the Neotropic cormorant.

\section{Avioserpens sp.}

Species of the Avioserpens genus usually occur in the subcutaneous tissue of piscivorous birds (Gibson, 1973; Wang et al., 1983). Nine species have been recognized in different domestic and wild birds, most of them in the Northern Hemisphere. For instance, Avioserpens mosgovoyi Supryaga, 1965 was identified in Podiceps cristatus, 
Podiceps grisigena, Podiceps ruficollis (Podicipedidae), Gavia arctica (Gaviidae), Anas platyrhynchos, Aythya ferina, Anser sp. (Anatidae), and Fulica atra (Rallidae) in Russia and in Alectoris rufa (Phasianidae) in the Canary Islands (Gibson, 1973; Cordero del Campillo et al., 1994); Avioserpens galliardi Chabaud \& Campana, 1949 in Egretta garzetta in France, Ixobrychus minutus in Italy, Ardea cinerea in Slovenia, E. garzetta, A. cinerea, Ardea purpurea, A. alba, N. nycticorax, Botaurus stellaris (Ardeidae), Gavia stellata (Gaviidae), and Mergus merganser (Anatidae) in the Palearctic region, and N. nycticorax, I. minutus, A. purpurea, and E. garzetta in Spain (Chabaud \& Campana, 1949; Daiya, 1967; Baruš et al., 1978; Brglez, 1982; Nogueserola et al., 2002; Santoro et al., 2016); Avioserpens denticulophasma Wehr \& Chitwood, 1934 in A. alba, Anhinga anhinga (Anhingidae), Anas fulvigula, and A. platyrhynchos (Anatidae) in the United States (Wehr, 1934; Wehr \& Chitwood, 1934); Avioserpens taiwana Sugimoto, 1919 in A. platyrhynchos, Cairina moschata domesticus (Anatidae), and Gallus gallus domesticus (Phasianidae) in China and Anas boschas and C. m. domesticus in Taiwan and Vietnam (Sugimoto, 1934; Chabaud et al., 1950), Avioserpens nana Mawson, 1957 in A. herodias in Canada (Mawson, 1957); Avioserpens multipapillosa Singh, 1949 in Ardeola grayii (Ardeidae) in India (Deshmukh, 1971); Avioserpens bifidus Olsen, 1952 in Bucephala islandica (Anatidae) in the United States (Olsen, 1952) and Avioserpens sp. in B. lentiginosus in Canada, Cygnus melancoryphus (Anatidae) in Chile, N. nycticorax in Brazil, Aechmophorus occidentalis (Podicipedidae) in the United States, and I. minutus and Plegadis falcinellus (Threskiornithidae) in Iraq (Gibson, 1973; Arruda et al., 2001; González-Acuña et al., 2010; Al-Salim \& Ali, 2010; Latas et al., 2016). This is the first time that Avioserpens sp. is recorded in the Neotropic cormorant.

\section{C. (C.) phenisci}

The genus Cyathostoma is composed of more than twenty species that parasitize sixteen different avian orders around the planet (Kanarek et al., 2013). Fish-eating birds are parasitized by the subgenus Cyathostoma, represented by species Cyathostoma (C.) lari (gulls), C. (C.) phenisci (penguins and cormorants), Cyathostoma (C.) verrucosum (pelicans and storks), Cyathostoma (C.) trifurcatum (Ciconia nigra), and Cyathostoma (C.) microspiculum (cormorants) (Kanarek et al., 2013; Oyarzún-Ruiz \& Muñoz-Alvarado 2015). Cyathostoma (C.) microspiculum has been reported in P. carbo and M. pygmaeus in Asia and Europe and possibly in N. (P.) auritus in North America (Kanarek, 2009; Kanarek \& Zaleśny, 2014). Cyathostoma (C.) phenisci is the only species reported previously in a Chilean cormorant, Phalacrocorax atriceps (Oyarzún-Ruiz \& Muñoz-Alvarado, 2015). This study is the first report of $C$. (C.) phenisci in the Neotropic cormorant.

\section{Acanthocephala}

Andracantha phalacrocoracis (Figure 5a), Profilicollis altmani Perry, 1942 (Figure 5b) and Corynosoma arctocephali (Figure $5 c$ ) were identified in cormorants' carcasses in this study. Corynosoma arctocephali has been previously reported in $N$. (P.) brasilianus in Chile (Torres et al., 1993). Information about population parameters for Acanthocephala recorded in this study can be found in Table 1.

\section{A. phalacrocoracis}

Andracantha Schmidt, 1975 is a cosmopolitan genus that parasitizes cormorants and other piscivorous birds (Schmidt, 1975). There are seven species within the genus described to this date: Andracantha baylisi Zdzitowiecki, 1986, Andracantha clavata Goss, 1940, Andracantha gravida Alegret, 1941, Andracantha mergi Lundstrom, 1941, Andracantha tandemtesticulata Monteiro, 2006, Andracantha tunitae Weiss, 1914, and A. phalacrocoracis (Monteiro et al., 2006a). Andracantha phalacrocoracis has been described in Urile pelagicus (Phalacrocoracidae) in the United States and Japan, P. carbo in Czech Republic, Haliaeetus leucocephalus (Accipitridae) in the United States, and N. (P.) brasilianus in Brazil (Schmidt, 1975; Našincová et al., 1993; Richardson \& Cole, 1997; Aznar et al., 2006; Monteiro et al., 2006a). Findings in this study expand the distributional range of $A$. phalacrocoracis to Chile.

\section{P. altmani}

The genus Profilicollis Meyer, 1931 is composed of nine species, which use crustaceans as intermediary hosts and parasitizes seabirds as their definitive host (Rodríguez et al., 2017). Profilicollis antarcticus Zdzitowiecki, 1985, Profilicollis chasmagnathi Holcman-Spector, Mañé-Garzón and Dei-Cas, 1977, and P. altmani have been recorded in South America (Rodríguez et al., 2017), with the latter having a Pan-American distribution (Rodríguez \& D'Elía, 2017). Along the Pacific coast of South America, P. altmani uses the Pacific mole crab (Emerita analoga) as 

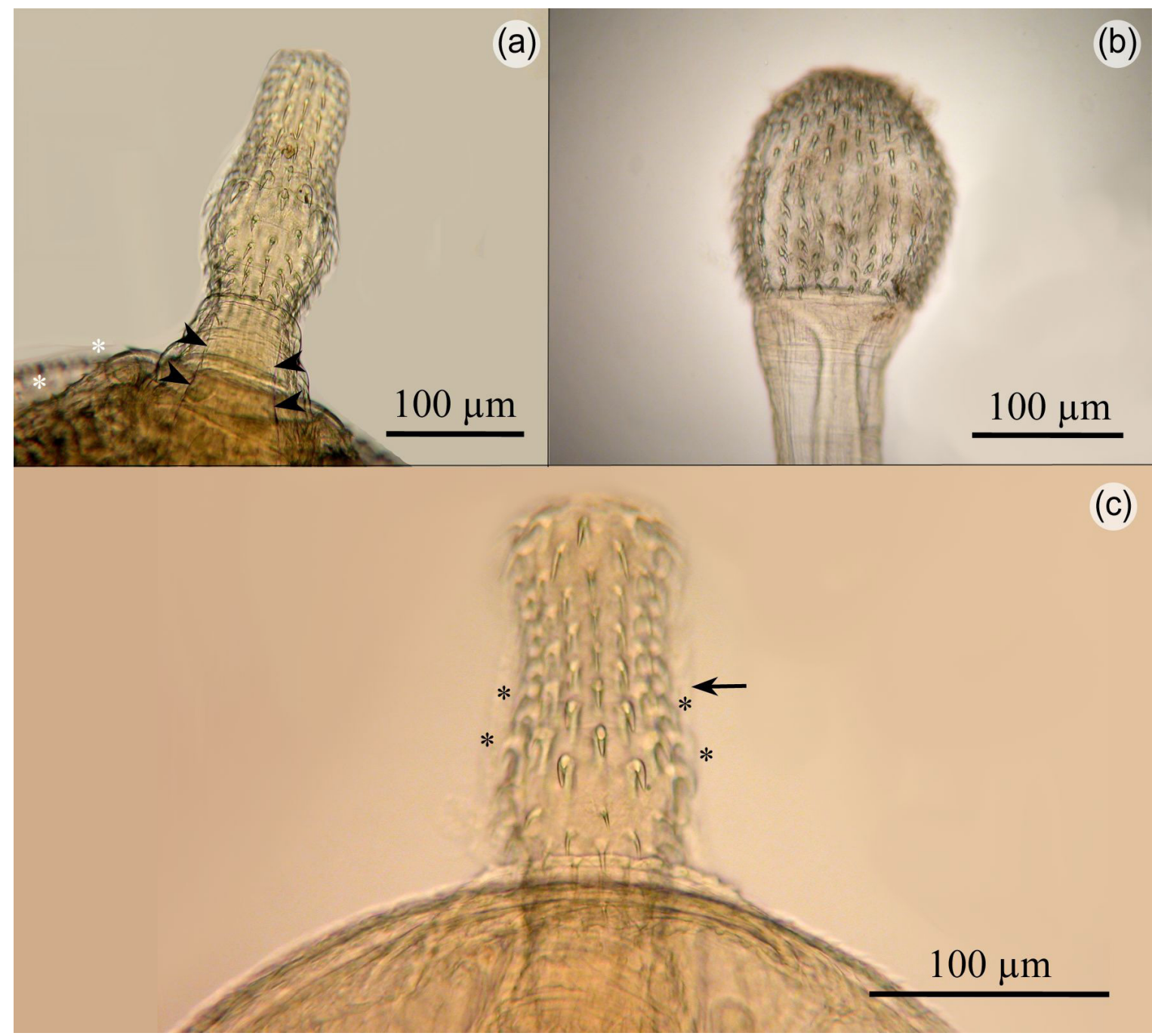

Figure 5. (a) Andracantha phalacrocoracis showing its cylindrical proboscis swollen at its posterior half armed with several longitudinal rows of small hooks, neck lacking hooks (arrow heads), and trunk covered with small spines (asterisks) (400x magnification); (b) Profilicollis altmani with its typical spherical proboscis covered with several rows of small hooks and lacking hooks in the neck (400x magnification); (c) Corynosoma arctocephali showing its proboscis constricted at its middle area (arrow) and armed with larger hooks (asterisks) in comparison to hooks present in the anterior and posterior areas of the proboscis (400x magnification).

intermediate host and has been described in Larus belcheri, Leucophaeus modestus, and Larus pipixcan (Laridae) in Peru (Tantaleán et al., 2005) and Larus dominicanus, L. pipixcan (Laridae), Numenius phaeopus (Scolopacidae), Podiceps occipitalis (Podicipedidae), and Egretta sp. (Ardeidae) in Chile (Riquelme et al., 2006). This study reports $P$. altmani in the Neotropic Cormorant for the first time.

This is the first report of P. altmani, B. carbonis, Avioserpens sp., C. (C.) phenisci, and E. pelucida in the Neotropic cormorant. In addition, these findings expand the distributional range of A. phalacrocoracis, P. caballeroi, H. triloba, and P. gyroceras to Chile.

In this study, a total of 13 parasite morphs were collected from Neotropic cormorant, 11 of which were described to the species level. Most of these descriptions are new records for Chile. Lice $P$. gyroceras and E. pellucida, trematodes A. felippei and H. triloba, nematodes C. rudolphii s. I., B. carbonis, and C. (C.) phenisci, cestode P. caballeroi, and acanthocephalans A. phalacrocoracis, C. arctocephali, and P. altmani are, in most cases, parasite species distributed in different geographical areas of the American continent. There are some species, such as $H$. triloba, that are cosmopolitan and have been recorded in a wide range of hosts. Although this study describes their presence in Chile for the first time, it is likely that they have been present in the country since the establishment of parasite-host associations with local wildlife. Conversely, it is also possible that some of these species were introduced into the country through parasitized migratory birds that arrive seasonally to spend the summer in the Southern 
Hemisphere (Martínez \& González, 2017). Nonetheless, molecular studies are necessary in order to test this latter hypothesis, which will most likely involve the application of molecular tools to study parasite populations in their different distribution areas.

\section{Acknowledgements}

We are deeply grateful for the support granted by members of the National Forest Corporation (CONAF) and the Agricultural and Livestock Service (SAG) of Chile. We also thank Karen Ardiles, Xotschlit Zepeda, Sofía González, Carolina Silva and Félix Varas for their support in the field and laboratory. Sebastián Muñoz-Leal reviewed the Portuguese "Resumo". Thank to Project FONDECYT 1170972.

\section{References}

Aguirre-Macedo ML, García-Magaña L. Metacercarias de cíclidos nativos del Sureste de México; taxonomía y claves para su reconocimiento. Univ Cienc 1994; 11(21): 5-35. http://dx.doi.org/10.19136/era.a11n21.612.

Alda P, Martorelli SR, Sarria R. Digenean Parasites in the White-Backed Stilt Himantopus melanurus Vieillot, 1817 (Recurvirostridae) from the Argentine Coast. Comp Parasitol 2011; 78(1): 217-219. http://dx.doi.org/10.1654/4479.1.

Al-Salim NK, Ali AH. First record of five nematode species in some water birds from Al-Hammar marsh, south of Iraq. Bull Iraq Nat Hist Mus 2010; 11(2): 39-53.

Arruda VS, Pinto RM, Muniz-Pereira LC. New host and geographical records for helminths parasites of Ardeidae (Aves, Ciconiiformes) in Brazil. Rev Bras Zool 2001; 18(Suppl 1): 225-232. http://dx.doi.org/10.1590/S0101-81752001000500018.

Aznar FJ, Pérez-Ponce de León G, Raga JA. Status of Corynosoma (Acanthocephala: Polymorphidae) based on anatomical, ecological, and phylogenetic evidence, with the erection of Pseudocorynosoma n. gen. J Parasitol 2006; 92(3): 548-564. http:// dx.doi.org/10.1645/GE-715R.1. PMid:16883999.

Barreto M, Burbano ME, Proctor HC, Mironov SV, Wauthy G. Feather mites (Acariformes: Psoroptidia) from Colombia: Preliminary list with new records. Zootaxa 2012; 3516(1): 1-68. http://dx.doi.org/10.11646/zootaxa.3516.1.1. PMid:23847408.

Baruš V, Sergeeva TP, Sonin MD, Ryzhikov KM. Helminths of fish-eating birds of the Palaearctic Region. 1. Nematoda. Prague: Springer Science; 1978. http://dx.doi.org/10.1007/978-94-009-9972-5.

Baruš V, Sergeeva TP. Capillariids parasitic in birds in the Palaearctic Region 3. Genus Baruscapillaria. Acta Sci Nat Brno 1990; 24(10): 1-53.

Bjoersdorff A, Bergstrom S, Massung RF, Haemig PD, Olsen B. Ehrlichia-infected ticks on migrating birds. Emerg Infect Dis 2001; 7(5): 877-879. http://dx.doi.org/10.3201/eid0705.017517. PMid:11747702.

Boch J, Supperer R. Parasitología en medicina veterinaria. Buenos Aires: Hemisferio Sur; 1982.

Boero JJ, Led JE, Brandetti E. Algunos parásitos de la avifauna argentina. Analecta Vet 1972; 4(1): 17-25.

Brglez J. Avioserpens galliardi and Ingliseria cirrohamata in birds from Slovenia. Zb Bio Fak Uni Edv Kard Ljub Vet 1982; 19(2): 247-251.

Bush AO, Lafferty KD, Lotz JM, Shostak AW. Parasitology meets ecology on its own terms: Margolis et al. revisited. J Parasitol 1997; 83(4): 575-583. http://dx.doi.org/10.2307/3284227. PMid:9267395.

Carrera-Játiva PD, Rodríguez-Hidalgo R, Sevilla C, Jiménez-Uzcátegui G. Gastrointestinal parasites in the Galápagos Penguin Spheniscus mendiculus and the Flightless Cormorant Phalacrocorax harrisi in the Galápagos Islands. Mar Ornithol 2014; 42: 77-80.

Carss DN. Techniques for assessing cormorant diet and food intake: towards a consensus view. Suppl Ric Biol Selvaggina 1997; 26: 197-230.

Cattán P, Tagle L. Estudio preliminar de la helmintiasis gastrointestinal en el conejo silvestre Oryctolagus cuniculus. Rev Soc Med vet Chile 1974; 24(1): 34-42.

Chabaud AG, Campana U, Truong-Tan-Ngoc. Note sur les dracunculides d'oiseaux. Ann Parasitol Hum Comp 1950; 25(4): 335-339. http://dx.doi.org/10.1051/parasite/1950254335. PMid:14790467.

Chabaud AG, Campana Y. Avioserpens galliardi n. sp. parasite de l'aigrette Egretta garzetta, L. Ann Parasitol Hum Comp 1949; 24(12): 67-76. http://dx.doi.org/10.1051/parasite/1949241067. PMid:18131387.

Chandler AC, Rausch R. A contribution to the study of certain avian strigeids (Trematoda).J Parasitol 1948; 34(3): 207-210. http:// dx.doi.org/10.2307/3273266. PMid:18867395. 
Chester S. A wildlife guide to Chile: Continental Chile, Chilean Antarctica, Easter Island, Juan Fernandez Archipelago. Princeton: Princeton University Press; 2008.

Clay T. The species groups of Pectinopygus (Phthiraptera: philopteridae). Bull Br Mus Nat Hist Entomol Ser 1973; 29(4): $203-223$.

Cordero del Campillo M, Castañón L, Reguera A. Indice catálogo de zooparásitos ibéricos. 2nd ed. León: Secretariado de Publicaciones Universidad de León; 1994.

Daiya GG. Nematodes of fish-eating birds of the lower Ob. In: Ryzhikov KM, editor. Sbornik rabot po gel'mintofaune ryb i ptits. Moscow: Izdat Akad Nauk SSSR; 1967. p. 133-153.

Dale W. Mallophaga (Hexapoda) en aves de la costa y sierra centrales del Perú [dissertation]. Lima: Universidad Nacional Agraria La Molina; 1970.

Deem SL, Merkel J, Ballweber L, Vargas FH, Cruz MB, Parker PG. Exposure to Toxoplasma gondii in Galapagos Penguins (Spheniscus mendiculus) and Flightless Cormorants (Phalacrocorax harrisi) in the Galapagos Island, Ecuador.J Wildl Dis 2010; 46(3): 1005-1011. http://dx.doi.org/10.7589/0090-3558-46.3.1005. PMid:20688714.

Deshmukh PG. On the male of Avioserpens multipapillosa Singh, 1949 from Ardeola grayii. Riv Parassitol 1971; 32(2): 101-103. PMid:5166875.

Drago FB, Lunaschi LI, Schenone M. Digenean parasites of the Neotropic cormorant, Phalacrocorax brasilianus (Gmelin, 1789) (Aves: Phalacrocoracidae) from Argentina: Distribution extension and new host records. Check List 2011; 7(6): 871-875. http:// dx.doi.org/10.15560/7.6.871.

Emerson KC. Notes on the Menoponidae of North America. I. Can Entomol 1947; 79(7-8): 135-141. http://dx.doi.org/10.4039/ Ent79135-7.

Fedynich AM, Pence DB, Bergan JF. Helminth community structure and pattern in sympatric populations of double-crested and Neotropic cormorants. J Helminthol Soc Wash 1997; 64(2): 176-182.

Forrester DJ, Spalding MG. Parasites and diseases of wild birds in Florida. Gainesville: University Press of Florida; 2003.

Frantová D. Capillariid nematodes (Nematoda: Capillariidae) parasitic in the common cormorant (Phalacrocorax carbo), with redescription of Baruscapillaria carbonis (Dubinin et Dubinina, 1940). Folia Parasitol (Praha) 2001; 48(3): 225-230. http://dx.doi. org/10.14411/fp.2001.037. PMid:11699658.

Gabor LJ, Srivastava M, Titmarsh J, Dennis M, Gabor M, Landos M. Cryptosporidiosis in intensively reared barramundi (Lates calcarifer). J Vet Diagn Invest 2011; 23(2): 383-386. http://dx.doi.org/10.1177/104063871102300235. PMid:21398470.

Garbin L, Mattiucci S, Paoletti M, González-Acuña D, Nascetti G. Genetic and morphological evidences for the existence of a new species of Contracaecum (Nematoda: Anisakidae) parasite of Phalacrocorax brasilianus (Gmelin) from Chile and its genetic relationships with congeners from fish-eating birds. J Parasitol 2011; 97(3): 476-492. http://dx.doi.org/10.1645/GE-2450.1. PMid:21506861.

García-Walther J, Senner NR, Norambuena HV, Schmitt F. Atlas de las aves playeras de Chile: sitios importantes para su conservación. Santiago: Universidad Santo Tomás; 2017.

Ghoneim NH, Abdel-Moein KA, Saeed H. Fish as a possible reservoir for zoonotic Giardia duodenalis assemblages. Parasitol Res 2012; 110(6): 2193-2196. http://dx.doi.org/10.1007/s00436-011-2748-y. PMid:22160281.

Gibson GG. Cardiofilaria pavlovskyi Strom, 1937 and Avioserpens sp. (Nematoda) from Canadian ciconiiform birds. Can J Zool 1973; 51(8): 847-851. http://dx.doi.org/10.1139/z73-126. PMid:4750285.

Giebel C. Die im zoologischen Museum der Universität Halle aufgestellten Epizoen nebst Beobachtungen über dieselben. Zeitschrift für die Gesammten der Naturwissenschaften 1866; 28: 353-397.

González-Acuña D, Moreno L, Cicchino A, Mironov S, Kinsella M. Checklist of the parasites of the black-necked swan, Cygnus melanocoryphus (Aves: Anatidae), with new records from Chile. Zootaxa 2010; 2637(1): 55-68. http://dx.doi.org/10.11646/ zootaxa.2637.1.3.

Gupta R. On two new diplostome parasites of birds, with a note on Hysteromorpha triloba (Rud., 1819) Lutz, 1931 from India (Trematoda: diplostomatidae). Rev Biol Trop 1963; 11(1): 75-87.

Hastriter MW. Ceratophyllus altus Tipton and Mendez (Siphonaptera: Ceratophyllidae) in Chile, with notes on the distribution of the genus Ceratophyllus Curtis 1832 in the southern hemisphere. Proc Entomol Soc Wash 2001; 103(3): 582-585.

Hernandes FA, Mironov SV, Bauchan GR, Ochoa RA. A new asymmetrical feather mite of the genus Michaelia Trouessart, 1884 (Astigmata: Freyanidae) from the Neotropical Cormorant, Phalacrocorax brasilianus (Pelecaniformes). Acarologia 2016; 56(1): 45-61. http://dx.doi.org/10.1051/acarologia/20162187. 
Hinojosa-Sáez A, González-Acuña D. Estado actual del conocimiento de helmintos en aves silvestres de Chile. Gayana 2005; 69(2): 241-253. http://dx.doi.org/10.4067/S0717-65382005000200004.

Hugghins EJ. Life history of a strigeid trematode, Hysteromorpha triloba (Rudolphi, 1819) Lutz, 1931. I. Egg and miracidium. Trans Am Microsc Soc 1954a; 73(1): 1-15. http://dx.doi.org/10.2307/3224180.

Hugghins EJ. Life history of a strigeid trematode, Hysteromorpha triloba (Rudolphi, 1819) Lutz, 1931. II. Sporocyst through adult. Trans Am Microsc Soc 1954b; 73(3): 221-236. http://dx.doi.org/10.2307/3224061.

International Union for Conservation of Nature and Natural Resources - IUCN. Phalacrocorax brasilianus. In International Union for Conservation of Nature and Natural Resources - IUCN. The IUCN Red List of Threatened Species [online]. Cambridge: IUCN; 2017. http://dx.doi.org/10.2305/IUCN.UK.2016-3.RLTS.T22696773A93585558.en.

Jenssen BM. Review article: effects of oil pollution, chemically treated oil, and cleaning on thermal balance of birds. Environ Pollut 1994; 86(2): 207-215. http://dx.doi.org/10.1016/0269-7491(94)90192-9. PMid:15091638.

Johnston TH. Trematodes from Australian birds. I. Cormorants and darters. Trans R Soc S Aust 1942; 65(2): $226-242$.

Kanarek G, Horne EC, Zaleśny G. Cyathostoma (Cyathostoma) phenisci Baudet, 1937 (Nematoda: Syngamidae), a parasite of respiratory tract of African penguin Spheniscus demersus: Morphological and molecular characterisation with some ecological and veterinary notes. Parasitol Int 2013; 62(5): 416-422. http://dx.doi.org/10.1016/j.parint.2013.05.002. PMid:23684707.

Kanarek G, Sitko J, Rolbiecki L, Rokicki J. Digenean fauna of the great cormorant Phalacrocorax carbo sinensis (Blumenbach, 1798) in the brackish waters of the Vistula Lagoon and the Gulf of Gdańsk (Poland). Wiad Parazytol 2003; 49(3): 293-299. PMid:16889033.

Kanarek G, Zaleśny G. Extrinsic-and intrinsic-dependent variation in component communities and patterns of aggregations in helminth parasites of great cormorant (Phalacrocorax carbo) from N.E. Poland. Parasitol Res 2014; 113(3): 837-850. http://dx.doi. org/10.1007/s00436-013-3714-7. PMid:24297694.

Kanarek G. The occurrence of Cyathostoma (Cyathostoma) microspiculum (Skrjabin, 1915) (Nematoda: Syngamidae) in the great cormorant [Phalacrocorax carbo (L., 1758)] in north-eastern Poland.J Helminthol 2009; 83(4): 391-398. http://dx.doi.org/10.1017/ S0022149X09990307. PMid:19531273.

Keler S. Uber eine neue gattung von Mallophagen, Eidmaniella n. gen. Ann Mus Zool Pol 1938; 13: 81-87.

Kennedy M, Spencer HG. Classification of the cormorants of the world. Mol Phylogenet Evol 2014; 79: 249-257. http://dx.doi. org/10.1016/j.ympev.2014.06.020. PMid:24994028.

Khalil LF, Jones A, Bray RA. Keys to the cestode parasites of vertebrates. Wallingfrord: CAB International; 1994.

Kornyushin VV. Cormorant (Phalacrocorax carbo L.) as a potential source of the helminthosis spreading in fish, game-birds and fowls. Branta 2008; 11: 200-203.

Kuabara KM, Valim MP. New records of chewing lice (Insecta, Phthiraptera) from Brazilian birds (Aves) collected by Helmut Sick (1910-1991). Rev Bras Entomol 2017; 61(2): 146-161. http://dx.doi.org/10.1016/j.rbe.2016.12.006.

Kuiken T, Leighton FA, Wobeser G, Wagner B. Causes of morbidity and mortality and their effect on reproductive success in double-crested cormorants from Saskatchewan. J Wildl Dis 1999; 35(2): 331-346. http://dx.doi.org/10.7589/0090-3558-35.2.331. PMid:10231760.

Lamont MA. A new species of Clinostomum. Ocass Pap Mus Zool 1920; 83: 1-5.

Latas PJ, Stockdale Walden HD, Bates L, Marshall S, Rohr T, Whitehead LR. Avioserpens in the Western Grebe (Aechmophorus occidentalis): A new Host and Geographic Record for a Dracunculoid Nematode and Implications of Migration and Climate Change. J Wildl Dis 2016; 52(1): 189-192. http://dx.doi.org/10.7589/2015-06-169. PMid:26555111.

Lebedeva DI, Chantuu K. New data on bird helminths in Mongolia. Parazitologiia 2015; 49(4): 304-308. PMid:26827489.

Leigh WH. Observations on life-histories of members of the genus Ascocotyle Looss (Heterophyidae). J Parasitol 1956; 42 (4): 39.

León C, Benítez-Mora A. Guía de campo avifauna presente en el sector adyacente al Canal El Morro, Humedal Rocuant-Andalién, Octava Región, Chile. Talcahuano: Dirección de Medio Ambiente; 2005.

Lunaschi L, Drago F. Primer registro de Neodiplostomum travassosi (Digenea: Diplostomidae) en Argentina. Rev Mex Biodivers 2005; 76(1): 97-100. http://dx.doi.org/10.22201/ib.20078706e.2005.001.353.

Malcomson RO. Mallophaga from birds of North America. Wilson Bull 1960; 72(2): 182-197.

Martínez DE, González GE. Aves de Chile: guía de campo y breve historia natural. Santiago, Chile: Ediciones del Naturalista; 2017.

Mateo MM. Diversidad y distribución de las especies de Mallophaga (Insecta) en aves y mamíferos de la comunidad de Madrid. Graellsia 2006; 62(Extra): 21-32. http://dx.doi.org/10.3989/graellsia.2006.v62.iExtra.108.

Mawson PM. Filariid nematodes from Canadian birds. Can J Zool 1957; 35(2): 213-219. http://dx.doi.org/10.1139/z57-018. 
Medema GJ. Cryptosporidium and Giardia: new challenges to the water industry [dissertation]. Utrecht: University of Utrecht; 1999.

Mironov SV. A review of the feather mite genus Scutomegninia Dubinin, 1951 (Acarina: Analgoidea: Avenzoariidae). Acarina 2000; 8(1): 9-58.

Mironov SV. Allopsoroptoides galli n. g., n. sp., a new genus and species of feather mites (Acari: Analgoidea: Psoroptoididae) causing mange in commercially raised domestic chicken in Brazil. Syst Parasito/ 2013; 85(3): 201-212. http://dx.doi.org/10.1007/ s11230-013-9422-y. PMid:23793494.

Monteiro C, Amato J, Amato S. A new species of Andracantha Schmidt (Acanthocephala, Polymorphidae) parasite of Neotropical cormorants, Phalacrocorax brasilianus (Gmelin) (Aves, Phalacrocoracidae) from southern Brazil. Rev Bras Zool 2006a; 23(3): 807812. http://dx.doi.org/10.1590/S0101-81752006000300027.

Monteiro C, Amato J, Amato S. Helminth parasitism in the Neotropical cormorant, Phalacrocorax brasilianus, in Southern Brazil: effect of host size, weight, sex, and maturity state. Parasitol Res 2011; 109(3): 849-855. http://dx.doi.org/10.1007/s00436-0112311-x. PMid:21431903.

Monteiro C, Amato J, Amato S. Primeiro registro de Syncuaria squamata (Linstow) (Nematoda, Acuariidae) em biguás, Phalacrocorax brasilianus (Gmelin) (Aves, Phalacrocoracidae) no Brasil. Rev Bras Zoo/ 2006b; 23(4): 1268-1272. http://dx.doi.org/10.1590/S010181752006000400041.

Monteiro C, Amato J, Amato S. Prosthogonimus ovatus (Rudolphi) (Digenea, Prosthogonimidae) em três espécies de aves aquáticas da Região Sul do Brasil. Rev Bras Zool 2007; 24(1): 253-257. http://dx.doi.org/10.1590/S0101-81752007000100035.

Moravec F, Scholz T, Našincová V. The systematic status of Trichosoma carbonis Rudolphi, 1819 and a description of Baruscapillaria rudolphii n. sp. (Nematoda: Capillariidae), an intestinal parasite of cormorants. Syst Parasito/ 1994; 28(2): 153-158. http://dx.doi. org/10.1007/BF00009593.

Moreno L, González-Acuña D. Los parásitos de las aves rapaces de Chile: una revisión. Bol Chil Ornitol 2015; 21 (1-2): 93-102.

Našincová V, Moravec F, Scholz T. Trematodes of the common cormorant (Phalacrocorax carbo) in Czech Republic. Acta Soc Zool Bohem 1993; 57(1): 31-46.

Nogueserola ML, Navarro P, Lluch J. Helmintos parásitos de Ardeidae en Valencia (España). An Biol 2002; 24: 139-144.

Olsen OW. Avioserpens bifidus, a new species of nematode (Dracunculidae) from ducks. Trans Am Microsc Soc 1952; 71(2): 150153. http://dx.doi.org/10.2307/3223075.

Ortega-Olivares MP, Garcia-Prieto L, Garcia-Varela M. Gryporhynchidae (Cestoda: Cyclophyllidea) in Mexico: species list, hosts, distribution and new records. Zootaxa 2014; 3795(2): 101-125. http://dx.doi.org/10.11646/zootaxa.3795.2.1. PMid:24870465.

Ostrowski de Núñez M. Fauna de agua dulce en la República Argentina. VI. Las cercarias de Ascocotyle (A.) tenuicollis Price 1935 y de Pygidiopsis pindoramensis Travassos 1929 (Trematoda, Heterophyidae). Physis, Secc B 1976; 35(90): 51-57.

Oyarzún-Ruiz P, González-Acuña D. Colecta, preparación e identificación de parásitos. Parasitol Latinoam 2020; 69(1): 12 -29.

Oyarzún-Ruiz P, Muñoz-Alvarado P. Cormorán imperial, Phalacrocorax atriceps (Aves, Phalacrocoracidae): Nuevo hospedero para un parásito respiratorio, Cyathostoma (Cyathostoma) phenisci (Nematoda, Syngamidae). Rev Biol Mar Oceanogr 2015; 50(2): 353-358. http://dx.doi.org/10.4067/S0718-19572015000300013.

Palma R. Slide-mounting of lice: a detailed description of the Canada balsam technique. N Z Entomo/ 1978; 6(4): 432-436. http:// dx.doi.org/10.1080/00779962.1978.9722313.

Pedroso LGA, Hernandes FA. New records of feather mites (Acariformes: Astigmata) from non-passerine birds (Aves) in Brazil. Check List 2016; 12(6): 1-25. http://dx.doi.org/10.15560/12.6.2000.

Pence DB, Spalding MG, Bergan JF, Cole RA, Newman S, Gray PN. New records of subcutaneous mites (Acari: Hypoderatidae) in birds, with examples of potential host colonization events. J Med Entomol 1997; 34(4): 411-416. http://dx.doi.org/10.1093/ jmedent/34.4.411. PMid:9220674.

Plutzer J, Tomor B. The role of aquatic birds in the environmental dissemination of human pathogenic Giardia duodenalis cysts and Cryptosporidium oocysts in Hungary. Parasitol Int 2009; 58(3): 227-231. http://dx.doi.org/10.1016/j.parint.2009.05.004. PMid:19446039.

Presswell B, Poulin R, Randhawa HS. First report of a gryporhynchid tapeworm (Cestoda: Cyclophyllidea) from New Zealand and from an eleotrid fish, described from metacestodes and in vitro-grown worms. J Helminthol 2012; 86(4): 453-464. http://dx.doi. org/10.1017/S0022149X11000691. PMid:22152219.

Price EW. Description of some heterophyid trematodes of the subfamily Centrocestinae. Proc Helminthol Soc Wash 1935; 2(2): 70-73.

Price RD, Hellenthal RA, Palma RL, Johnson KP, Clayton DH. The chewing lice: world checklist and biological overview. Champaign: Illinois Natural History Survey; 2003. 
Price RD. The Piagetiella (Mallophaga: Menoponidae) of the Pelecaniformes. Can Entomol 1970; 102(4): 389-404. http://dx.doi. org/10.4039/Ent102389-4.

Pritchard MH, Kruse GOW. The collection and preservation of animal parasites. Lincoln: University of Nebraska Press; 1982.

Richardson DJ, Cole RA. Acanthocephala of the bald eagle (Haliaeetus leucocephalus) in North America. J Parasitol 1997; 83(3): 540-541. http://dx.doi.org/10.2307/3284428. PMid:9194845.

Riquelme C, George-Nascimento M, Balboa L. Morfometría y fecundidad de Profilicollis bullocki Mateo, Córdova \& Guzmán 1982 (Acanthocephala: Polymorphidae) en especies simpátricas de aves costeras de Chile. Rev Chil Hist Nat 2006; 79(4): 465-474. http:// dx.doi.org/10.4067/S0716-078X2006000400005.

Robinson SA. Parasitism and contaminants: relationships and underlying mechanisms for a model endohelminth-bird association [dissertação]. Ottawa: Carleton University; 2011.

Rodríguez SM, D'Elía G. Pan-American marine coastal distribution of the acanthocephalan Profilicollis altmani based on morphometric and phylogenetic analyses of cystacanths from the mole crab Emerita brasiliensis. J Helminthol 2017; 91(3): 371375. http://dx.doi.org/10.1017/S0022149X16000237. PMid:27126405.

Rodríguez SM, Diaz JI, D'Elía G. Morphological and molecular evidence on the existence of a single estuarine and rocky intertidal acanthocephalan species of Profilicollis Meyer, 1931 (Acanthocephala: Polymorphidae) along the Atlantic and Pacific coasts of southern South America. Syst Parasitol 2017; 94(4): 527-533. http://dx.doi.org/10.1007/s11230-017-9716-6. PMid:28337681.

Ryan S, Price RD. A review of the genus Eidmanniella (Mallophaga: Menoponidae) from the Pelecaniformes. Ann Entomol Soc Am 1969; 62(4): 815-823. http://dx.doi.org/10.1093/aesa/62.4.815.

Rzymski P, Slodkowicz-Kowalska A, Klimaszyk P, Solarczyk P, Poniedzialek B. Screening of protozoan and microsporidian parasites in feces of great cormorant (Phalacrocorax carbo). Environ Sci Pollut Res Int 2017; 24(10): 9813-9819. http://dx.doi.org/10.1007/ s11356-017-8652-y. PMid:28255818.

Santoro M, D'Alessio N, Di Prisco F, Veneziano V, Galiero G, Cerrone A, et al. Helminth communities of herons (Aves: Ardeidae) in southern Italy. Parasitol Int 2016; 65(4): 340-346. http://dx.doi.org/10.1016/j.parint.2016.04.002. PMid:27091547.

Santos A, López OG, Miller M. Hippoboscidae (Insecta: Diptera).Ectoparásitos en aves de Panamá, claves de identificación, hospederos y distribución. Scientia 2014; 24(1): 49-68.

Schmidt GD. Andracantha, a new genus of Acanthocephala (Polymorphidae) from fish-eating birds, with descriptions of three species. J Parasitol 1975; 61(4): 615-620. http://dx.doi.org/10.2307/3279453. PMid:1165545.

Scholz T, Aguirre-Macedo ML, Salgado-Maldonado G. Trematodes of the family Heterophyidae (Digenea) in Mexico: a review of species and new host and geographical records.J Nat Hist 2001; 35(12): 1733-1772. http://dx.doi.org/10.1080/00222930152667087.

Scholz T, Kuchta R, Salgado-Madonado G. Cestodes of the family Dilepididae (Cestoda: Cyclophyllidea) from fish-eating birds in Mexico: a survey of species. Syst Parasitol 2002; 52(3): 171-182. http://dx.doi.org/10.1023/A:1015700801579. PMid:12143788.

Sepúlveda MS, Spalding MG, Kinsella JM, Forrester DJ. Parasites of the great egret (Ardea albus) in Florida and a review of the helminths reported for the species. J Helminthol Soc Wash 1999; 66(1): 7-13.

Sepúlveda MS, Spalding MG, Kinsella JM, Forrester DJ. Parasitic helminths of the little blue heron, Egretta caerulea, in southern Florida. J Helminthol Soc Wash 1996; 63(1): 136-140.

Servicio Agrícola y Ganadero - SAG. La ley de caza y su reg/amento [online]. Chile; 2018 [cited 2020 May 19]. Available from: https:// www.sag.gob.cl/sites/default/files/ley_de_caza_2018.pdf

Sitko J, Okulewicz A. Checklist of the nematodes in birds in the Czech Republic and the Slovak Republic. Přerov: Comenius Museum; 2010.

Skrjabin KI, Shikobalova NP, Schulz RS. Essentials of nematodology. Moscow: USSR Academy of Sciences Press; 1954. (vol. III, Trichostrongylids of animals and man).

Skrjabin KI. Key to parasitic nematodes. Washington: National Science Foundation, Israel Program for Scientific Translations; 1961. (vol. III, Strongylata).

Skrjabin KI. Key to parasitic nematodes. Jerusalem: Israel Program for Scientific Translations; 1969. (vol. I, Spirurata and filariata).

Sugimoto M. On the filaria from the Formosan domesticated birds.JJap Soc Vet Sci 1934; 13(4): 261-266. http://dx.doi.org/10.1292/ jvms1922.13.261.

Švažas S, Chukalova N, Grishanov G, Pūtys Ž, Sruoga A, Butkauskas D, et al. The role of Great cormorant (Phalacrocorax carbo sinensis) for fish stock and dispersal of helminthes parasites in the Curonian Lagoon Area. Vet Med Zoot 2011; 55(77): 79-85.

Tantaleán M, Sánchez L, Gómez L, Huiza A. Acantocéfalos del Perú. Rev Peru Biol 2005; 12(1): 83-92. 
Torres P, Contreras A, Cubillos V, Gesche W, Montefusco A, Rebolledo C, et al. Parasitismo en peces, aves piscívoras y comunidades humanas ribereñas de los lagos Yelcho y Tagua-Tagua, X Región de Chile. Arch Med Vet 1992; 24(1): 77-92.

Torres P, Figueroa L, Saldivia A, Barrientos J. Gastrointestinal helminths of fish-eating birds from the Valdivia River, Chile. J Parasitol 1982; 68(6): 1157. http://dx.doi.org/10.2307/3281111.

Torres P, Ortega J, Schlatter R. Nematode parasites of the digestive tract in Neotropic cormorant chicks (Phalacrocorax brasilianus) from the River Cruces Ramsar site in southern Chile. Parasitol Res 2005; 97(2): 103-107. http://dx.doi.org/10.1007/s00436-0051372-0. PMid:15986255.

Torres P, Ruíz E, Gesche W, Montefusco A. Gastrointestinal helminths of fish-eating birds from Chiloe Island, Chile. J Wildl Dis 1991; 27(1): 178-179. http://dx.doi.org/10.7589/0090-3558-27.1.178. PMid:2023322.

Torres P, Schlatter R, Montefusco A, Gesche W, Ruiz E, Contreras A. Helminth parasites of piscivorous birds from lakes in the south of Chile. Mem Inst Oswaldo Cruz 1993; 88(2): 341-343. http://dx.doi.org/10.1590/S0074-02761993000200028. PMid:8107596.

Torres P, Valdivieso J, Schlatter R, Montefusco A, Revenga J, Marín F, et al. Infection by Contracaecum rudolphii (Nematoda: Anisakidae) in the Neotropic cormorant Phalacrocorax brasilianus, and fishes from the estuary of the Valdivia river, Chile. Stud Neotrop Fauna Environ 2000; 35(2): 101-108. http://dx.doi.org/10.1076/0165-0521(200008)35:2;1-9;FT101.

Travassos L, Teixeira de Freitas JF, Kohn A. Trematódeos do Brasil. Mem Inst Oswaldo Cruz 1969; 67(1): 1-886. PMid:5397756.

Tucci EC, Soares NM, Faccini JLH, Vilas Boas D. Additional information about a mange outbreak by Allopsoroptoides galli (Acari: Psoroptoididae) in commercial laying hens in the state of São Paulo, Brazil. Pesq Vet Bras 2014; 34(8): 760-762. http://dx.doi. org/10.1590/S0100-736X2014000800009.

Vicente J, Pinto RM, Noronha D, Carvalho PGD. Nematode parasites of Brazilian Pelecaniformes and Trogoniformes birds: a general survey with new records for the species. Rev Bras Zoo/ 1996; 13(4): 891-901. http://dx.doi.org/10.1590/S0101-81751996000400011.

Vicente J, Rodrigues HD, Gomes DC, Pinto RM. Nematóides do Brasil. Parte IV. Nematóides de aves. Rev Bras Zool 1995;12(1 Suppl 1): 1-273. http://dx.doi.org/10.1590/S0101-81751995000500001.

Víchová B, Reiterová K, Špilovská S, Blaňarová L, Hurníková Z, Turčeková L. Molecular screening for bacteria and protozoa in great cormorants (Phalacrocorax carbo sinensis) nesting in Slovakia, central Europe. Acta Parasitol 2016; 61(3): 585-589. http:// dx.doi.org/10.1515/ap-2016-0078. PMid:27447224.

Violante-González J, Monks S, Gil-Guerrero S, Rojas-Herrera A, Flores-Garza R, Larumbe-Morán E. Parasite communities of the neotropical cormorant Phalacrocorax brasilianus (Gmelin) (Aves, Phalacrocoracidae) from two coastal lagoons in Guerrero state, Mexico. Parasitol Res 2011; 109(5): 1303-1309. http://dx.doi.org/10.1007/s00436-011-2377-5. PMid:21503640.

Wang PQ, Sun YL, Zhao YR. Studies on the life history and epidemiology of Avioserpens taiwana (Sugimoto, 1919) of the domestic duck in Fujian. Dong Wu Xue Bao 1983; 29: 350-357.

Wehr EE, Chitwood BG. A new nematode from buds. Proc Helminthol Soc Wash 1934; 1: 10-11.

Wehr EE. A new host for the bird darcunculid (sic) Avioserpens denticulophasma. Proc Helminthol Soc Wash 1934; $1: 11$.

Yamaguti S. Studies on the helminth fauna of Japan. 25. Trematodes of birds IV. Jap J Zoo/ 1939; 8: $129-210$.

Yamaguti S. Systema Helminthum. New York: Interscience; 1958. (vol. I, The Digenetic Trematodes of Vertebrates. Part I and II). Yamaguti S. Systema Helminthum. New York: Interscience; 1959. (vol. II, The Cestodes of Vertebrates. Part I and II). Yamaguti S. Systema helminthum: the nematodes of vertebrates. New York: Interscience Publisher; 1961. (vol. 3).

Zajac AM, Conboy GA. Veterinary clinical parasitology. 8th ed. Ames: Wiley-BlackWell; 2012. 